\title{
PERLINDUNGAN VARIETS TANAMAN SEBAGAI SALAH SATU BENTUK PERLINDUNGAN HAK EKONOMI PARA PEMULIA TANAMAN MENUJU KETAHANAN PANGAN NASIONAL
}

\author{
Prasetyo Hadi Purwandoko, Moch Najib Imanullah \\ Fakultas Hukum Universitas Sebelas Maret Surakarta \\ Email: omprasetyohp@gmail.com; imanullahnajib@yahoo.com
}

\begin{abstract}
This paper is partly the result of prime research of Higher Education discusses the contribution of legislation in the field of food PVP and protect the economic rights of breeders of plant varieties that produce seeds crops. research conducted an empirical legal research. Data obtained from informants and analyzed using interactive models of analysis. The results showed that Indonesia as one of the country have little megabiodiversity germplasm that can be developed into high-yielding varieties. Although there is little genetic but basically each region has the potential to develop high yielding varieties through plant breeding and protected by pvp. pvp is a form of protection of the economic rights of plant breeders. Although each region has the potential for yielding varieties that can be requested, but the PVP application of knowledge communities and relevant agencies on the protection of plant varieties is still lacking. Legislation in the field of food has not been able to PVP and encourage breeders of plant varieties produce seed crops because they can not protect their economic rights. Draft a list of six National Legislation Program 2010-2014, only two bill that has been passed into law, the Act Number 13 of 2010 concerning Horticulture was passed in 2010 and the Act Number 18 of 2012 concerning Food was passed in 2012.
\end{abstract}

Keywords : protection of plant variety, protection of economic rights, food security

\begin{abstract}
Abstrak
Tulisan ini merupakan sebagian hasil Penelitian Unggulan Perguruan Tinggi yang membahas kontribusi perundang-undangan bidang PVT dan pangan dalam melindungi hak ekonomi pemulia varietas tanaman yang menghasilkan bibit unggul tanaman pangan. Penelitian yang dilakukan merupakan penelitian hukum empiris. Data diperoleh dari informan dan dianalisis dengan menggunakan interactive models of analysis. Hasil penelitian menunjukkan bahwa Indonesia sebagai salah satu negara megabiodiversity hanya mempunyai sedikit plasma nutfah yang dapat dikembangkan menjadi varietas unggul.. Meskipun hanya terdapat sedikit plasma nutfah tetapi pada dasarnya tiap daerah memiliki potensi varietas unggul yang dapat dikembangkan melalui kegiatan pemuliaan tanaman dan dilindungi melalui PVT. PVT merupakan salah satu bentuk perlindungan hak ekonomi para pemulia tanaman. Meskipun tiap-tiap daerah mempunyai potensi atas varietas unggul yang dapat dimintakan permohonan PVT tetapi pengetahuan masyarakat dan instansi terkait tentang perlindungan varietas tanaman masih kurang. Perundangundangan di bidang PVT dan pangan belum mampu mendorong pemulia varietas tanaman menghasilkan bibit unggul tanaman pangan karena belum dapat melindungi hak ekonomi mereka. Dari enam daftar RUU Program Legislasi Nasional tahun 2010-2014, baru dua RUU yang telah disahkan menjadi UU, yaitu Undang Undang Nomor 13 tahun 2010 tentang Hortikultura yang telah disahkan pada tahun 2010 dan Undang-Undang No 18 tahun 2012 tentang Pangan yang disahkan tahun 2012.
\end{abstract}

Kata kunsi : Perlindungan varietas tanaman, perlindungan hak ekonomi, ketahanan pangan

\section{A. Pendahuluan}

Salah satu alternatif mengatasi persoalan kurangnya produk dan berkurangnya luas lahan panen adalah apabila tersedia varietas dan bibit unggul yang dapat meningkatkan produktivitas. Ketersediaan varietas dan bibit yang unggul tersebut akan terpenuhi jika ada kegairahan pemulia maupun produsen untuk melakukan pemuliaan varietas. Ini akan mereka lakukan apabila karya mereka dihargai dan dilindungi, antara lain dengan perlindungan HKI melalui pemberian hak PVT. Kondisi yang kondusif ini memberikan sumbangan yang cukup signifikan terhadap upaya pencapaian ketahanan pangan nasional 
Perlindungan Varietas Tanaman (PVT) merupakan salah satu bentuk perlindungan Hak Kekayaan Intelektual (HKI). Perlindungan ini diberikan kepada pemulia tanaman atau pihak yang telah melakukan pemuliaan tanaman. Perlindungan $\mathrm{HKI}$ varietas tanaman banyak bermanfaat, seperti meningkatkan jumlah dan kecepatan varietas unggul baru yang kompetitif, meningkatkan kempetensi industri perbenihan, membendung membanjirnya produk impor, meningkatkan pendapatan petani, membuka lapangan kerja baru, meningkatkan penelitian pemuliaan, meningkatkan produktivitas, meningkatkan kualitas produktivitas pertanian, meningkatkan diversitas varietas, mengurangi ketergantungan pada bahan-bahan kimia, dan perluasan pertanian ke lahan-lahan marginal. Keuntungan-keuntungan tersebut akan bermuara pada pencapaian ketahanan pangan nasional.

Perlindungan tersebut juga diharapkan dapat mendorong kreativitas pemuliaan tanaman, sehingga dapat menghasilkan penemuan berbagai varietas unggul yang sangat diperlukan masyarakat. Untuk memberikan landasan hukum yang kuat bagi perlindungan varietas tanaman hasil pemuliaan dan hak pelaku pemuliaan, maka telah diundangkan Undang Undang Nomor 29 tahun 2000 tentang Perlindungan Varietas Tanaman (UUPVT) sejak tahun 2000.

Persoalan perlindungan varietas tanaman ini penting untuk diketahui karena apabila tidak ada perlindungan yang memadai maka akan timbul ketidakpuasan bagi pemulia, perasaan tidak adil, dan tidak menstimulasi untuk lebih inovatif (Adriana Krisnawati dan Gazalba Saleh, 2004). Dengan demikian hak ekonomi yang merupakan hak asasi para pemulia tanaman tidak terlindungi.

\section{B. Metode Penelitian}

Penelitian yang dilakukan merupakan penelitian hukum empiris yang mengkaji penggunaan peraturan perundang-undangan untuk mengatur dan mendukung kegiatan perekonomian masyarakat, dalam hal ini kegiatan pemuliaan varietas tanaman dalam upaya mencapai ketahanan pangan nasional dengan didukung data- di lapangan. Penelitian dilakukan di Kantor PVT Kementerian Pertanian, Badan Litbang Pertanian Propinsi Jawa Tengah, dan di Dinas Pertanian Tanaman Pangan dan Kehutanan: Kabupaten Klaten (untuk tanaman padi), Sragen (untuk yanaman jagung), dan Wonogiri (untuk tanaman ubi kayu). Penelitian menggunakan data primer yang berupa hasil wawancara dan observasi. Selain itu penelitian ini juga menggunakan data sekunder yang berkaitan dengan varietas unggul, permohonan hak PVT, penolakan dan permohonan yang dikabulkan, penerbitan sertifikat hak PVT, peraturan perundang-undangan Hak PVT, dan peraturan pangan, dan kebijakan ketahanan pangan (bahan hukum primer), dan kajian-kajian atau penelitian-penelitian yang telah dilakukan sebelumnya yang telah dipublikasikan dalam jurnal-jurnal penelitian yang mengkaji Hak PVT, varietas unggul, dan ketahanan pangan (bahan hukum sekunder). Data primer diperoleh melalui wawancara terstruktur kepada informan penelitian yang dipilih berdasarkan pertimbangan tertentu, yaitu kualitas informan terhadap penguasaan pengetahuan dan data yang dibutuhkan untuk menjawab permasalahan dan tujan penelitian. Selanjutnya, data dianalisis secara kualitatif dengan menggunakan interactive models of analysis.

\section{Hasil Penelitian dan Pembahasan}

\section{Varietas Tanaman sebagai HKI}

Hak Kekayaan Intelektual (HKI) dapat dideskripsikan sebagai hak kekayaan yang timbul atau lahir karena kemampuan intelektual manusia. Karya-karya intelektual tersebut di bidang ilmu pengetahuan, seni, sastra ataupun teknologi, dilahirkan dengan pengorbanan tenaga, waktu dan bahkan biaya. Adanya pengorbanan tersebut menjadikan karya yang dihasilkan menjadi memiliki nilai. Apabila ditambah dengan manfaat ekonomi yang dapat dinikmati, maka nilai ekonomi yang melekat menumbuhkan konsepsi kekayaan (property) terhadap karya-karya intelektual. Bagi dunia usaha, karya-karya itu dikatakan sebagai assets perusahaan. Dengan demikian, hak ini lahir karena kemampuan intelektual manusia.

Dalam konvensi World Intellectual property Organization (WIPO), IPR (HKI) diartikan: Intellectual property right is defined as "intellectual property shall include the rights relating lo: leterary, artistic and scientific works, inventions in all fields of human endeavor, scientific discoveries, industrial designs, trademarks, service makrs, and commercial names and designations, protection against unfair competition and all other rights from intellectual activity in the industrial, scientific or artistic fields" (Article 2). Selanjutnya, dalam Perjanjian TRIPS/World Trade Organization dinyatakan: "Intellectual property is defined as "The term intellectual property" refers to 
all categories of intellevtual property that are subject of section 1 through 7 of part II" (Article 1(2)). And...r, copyright and related rights (Section 1), trademarks (Section 2), geographical indications (Section 3), industrial designs (Section 4), patents (Section 5), layout designs of integrated circuits (Section 6), and protection of undisclosed information (Section 7) are stipulated in the Agreement. Di Jepang HKI diartikan (Sadayuki Hosai, 2001: 2): The world "intellectual property" is usually used to refer generallyu to mental works created through intellectual human activities, such as industrial property, including" a patent, a utility model, a design and a trademark, "and copyright.

Dengan demikian, HKI adalah segala sesuatu yang diciptakan melalui kegiatan intelektual seseorang. HKI juga dapat diartikan sebagai hak milik yang berasal dari kemampuan intelektual yang diekspresikan dalam bentuk ciptaan hasil kreativitas melalui berbagai bidang, seperti ilmu pengetahuan, teknologi, seni, sastra, desain dan sebagainya (Lihat juga Muhammad Jumhana dan R Djubaedillah, 1993: 16, Richard B, Simatupang, 1996: 84-85, Saidin, 1997: 9, Akira Okawa, 1997: 1). Zaid Hamzah dalam bukunya yang berjudul "Intellectual property Law \& Strategy" mengungkapkan (Zaid Hamzah, 2007: 19-121):

Intellectual property is society's recognition of intellectual efforts. It is monopoly granted in exchange fot the contribution of inteellcetual creation to the society. It is an intangible property. The use Ip by third party does not disprove the owne of his right of enjoyment. As such, an IP right is a right to restian others from using the right. The extent of this right is dependent upon the scope of the ablity granted by the law to restrain its us. The wider the scope given, the greater the monopoly an IP owner has. An IPR is a proprietary right which a person may exert over the use of his own intelligence. In so exerting this right, the person claims for himself a basic to protect his intelligence from being used by other without his permission. Through the growth and evolvement of law, this tight has become enforceable under the law of Iprs almost globally.

Ditinjau dari cara perwujudannya, HKI sebenarnya berbeda dari objek berwujud lainnya. Hal ini dapat digambarkan dalam kasus yang melibatkan seseorang pengarang terkenal yang bernama Charles Dickens
(Baca Tim Lindsey, 2002: 4-5). HKI termasuk hukum kebendaan yang tidak berwujud (intangible assets) terdiri atas industrial property rights (hak milik perindustrian) dan copyrights (Hak Cipta). Berdasarkan realita, sulit untuk membedakan pembagian tersebut karena sering menyatu satu sama lain dalam suatu produk atau obyek tertentu (baca Insan Budi Maulana, 2007: 6).

Dari beberapa pengertian tersebut, HKI merupakan istilah umum hak eksklusif yang diberikan sebagai hasil yang diperoleh dari kegiatan intelektual manusia dan sebagai tanda yang digunakan dalam kegiatan bisnis, dan termasuk ke dalam hak tak berwujud yang memiliki nilai ekonomis (baca JICA Team, 2002: 1). HKI adalah sistem yang memberikan apresiasi kepada para inventor, pendesain, pencipta dan pemegang karya intelektual lain. Hal ini tidak lain merupakan insentif (dan tentu saja kompensasi) bagi tumbuhnya karya-karya yang bermanfaat dan sangat diperlukan oleh masyarakat luas (baca A. Zen Umar Purba, 2001: 1). Inovasi teknologi sebagaimana peningkatan kekuatan ekonomi sangat dibutuhkan bagi pertumbuhan masyarakat dan pengembangan industri. Inovqasi teknologi dapat mendatangkan kemakmuran bagi kehidupan masyarakat, dan pengembangan teknologi mendorong pertumbuhan masyarakat (baca JICA Team, 2003: 1). Menurut Don HKI diibaratkan sebagai berikut. The new economy is a knowledge economy and the key assets of every firm become intellectual assets (Don Tapscot dalam Andy Noorsaman Sommeng, 2002: 1). Dalam New York Times dinyatakan, Kekayaan Intelektual telah berubah dari bidang hukum dan bisnis yang sepi menjadi salah satu mesin penggerak ekonomi teknologi tinggi. (New York Times, 9 April 1999). Pengembangan HKI pada hakekatnya merupakan pengembangan sumber daya manusia ("SDM"). Hal ini disebabkan oleh karena $\mathrm{HKI}$ berurusan dengan produk dan proses berkait olah pikir manusia. Pengembangan sistem HKI diharapkan akan berkembang pula SDM terutama terciptanya budaya inovatif dan inventif. Hal ini sangat penting dikaitkan dengan kenyataan, bahwa walaupun kekayaan atau sumber daya alam ("SDA") berlimpah, kita masih "begini-begini" saja bahkan mundur, dan tingkat kemiskinan makin bertambah (A. Zen Umar Purba, 2002:1). Hal ini sesuai dengan editorial The Washington Post, 28 April 2001 yang 
menyatakan: "... if there is one lesson in the past half century of economic development, it is that natural resources do not power economies, human resources do". Hal ini secara singkat dapat diartikan bahwa Sumber Daya Manusia (yang potensial menghasilkan kekayaan intelektual) lebih penting daripada Sumber Daya Alam.

Para ahli ekonomi selama bertahuntahun telah mencoba memberikan penjelasan mengenai adanya sebagian perekonomian yang dapat berkembang pesat, ada yang tidak. Secara umum disepakati bahwa HKI memegang peranan penting dalam pertumbuhan ekonomi saat ini. Akumulasi dari ilmu pengetahuan merupakan kekuatan pendorong bagi pertumbuhan ekonomi. Bagi negara yang ingin meningkatkan pertumbuhan ekonominya, maka kebijakankebijakan ekonomi yang dibuat haruslah mendorong investasi di bidang penelitian, pengembangan dan mensubsidi program untuk pengembangan sumber daya manusia. (Baca Kamil Idris dalam Prihaniwati, 2004:2). Keberadaan $\mathrm{HKI}$ dalam hubungan antar manusia dan antar negara merupakan sesuatu yang tidak dapat dipungkiri. HKI juga merupakan sesuatu yang given dan inheren dalam sebuah masyarakat industri atau yang sedang mengarah ke sana. Keberadaannya senantiasa mengikuti dinamika perkembangan masyarakat itu sendiri. Begitu pula halnya dengan masyarakat dan bangsa Indonesia yang mau tidak mau bersinggungan dan terlibat langsung dengan masalah $\mathrm{HKI}$ (http//:www.dgip.go.id).

Secara umum ada beberapa manfaat yang dapat diperoleh dari sistem HKI yang baik, yaitu (Prihaniwati, 2004:2): meningkatkan posisi perdagangan dan investasi,mengembangkan teknologi, mendorong perusahaan untuk bersaing secara internasional, dapat membantu komersialisasi dari suatu invensi, dapat mengembangkan sosial budaya, dan dapat menjaga reputasi internasional untuk kepentingan ekspor.

Menjelang era perdagangan bebas masalah HKI telah menjadi isu yang strategis. Adanya globalisasi ekonomi terutama bidang perdagangan dan industri berarti pula globalisasi HKI. Hal ini mengakibatkan negara-negara berkembang akan menjadi sasaran penerapan HKI milik negara-negara maju. Berdasarkan hasil penelitian para ahli UNESCO ternyata negara-negara majulah yang telah mendahulukan HKI. Dengan demikian, $\mathrm{HKI}$ berperan sangat penting di dunia internasional. Oleh karena itu, setiap negara wajib melindungi kreasi manusia (human creativity) untuk lebih mendorong kemajuan di bidang IPTEK dan seni.

$\mathrm{HKI}$ memang tidak mudah didefinisikan. Namun demikian dari istilah tersebut dapat diketahui bahwa hak tersebut merupakan hak yang berasal dari kekayaan intelektual seseorang. HKI sebagai terjemahan Intellectual property rights (Ipr), menurut WIpO (The World Intellectual property Organization) secara garis besar meliputi dua cabang yaitu:

a. Hak Cipta (copyright), dan

b. Hak Atas Kekayaan Industri (Industrial property right) yang terdiri atas:

1) Paten (patent)

2) Merek (Mark)

3) Desain Produksi Industri (Industrial Design);

4) Penanggulangan Praktek Persaingaan Curang (repression of Unfair competition practices).

Selanjutnya, berdasarkan Bab II Trade Related Aspects of Intellectual Property rights, Including Trade in counterfeit goods (Trlps), HKI meliputi:

a. Hak Cipta (copyright) dan Hak-hak yang terkait lainnya;

b. Merek (Mark);

c. Indikasi Geografis (geographical Indication);

d. Desain Produksi Industri (Industrial Design);

e. Paten (patent);

f. Rangkaian Elektronika Terpadu (Lay Out Design of Integrated circuit);

g. Perlindungan Rahasia Dagang (Undisclosed Information/Trade Secret);

h. Pengendalian terhadap Praktek Persaingan Curang/tidak sehat (repression Unfair competition practices).

Varietas Tanaman juga merupakan kekayaan intelektual. Hak atas Varietas Tanaman merupakan HKI. Oleh karena itu, Perlindungan Varietas Tanaman merupakan perlindungan $\mathrm{HKI}$.

Perlindungan Varietas Tanaman merupakan bentuk perlindungan berdasarkan pada sistem sui generis (Adriana Krisnawati\&Gazalba Saleh, 2004: hlm 114). Berdasarkan sistem ini maka masing-masing 
negara diberikan kebebasan memberikan perlindungan sesuai kebutuhannya masingmasing. Sistem ini diperlukan karena varietas tanaman memiliki kekhususan sendiri sehingga tidak dapat dimasukkan dalam sistem HKI lain.

Kekhususan PVT terletak pada adanya sifat stabilitas karakter pada varietas tanaman, meskipun demikian sistem sui generis ini pada dasarnya memiliki persamaan dengan ketentuan paten yang bersifat umum (Adriana Krisnawati\&Gazalba Saleh, 2004: hlm 114). PVT yang memberikan perlindungan kepada pemulia tanaman didasarkan pada Pasal 27 ayat (3) huruf b TRIP's Agreement. Secara khusus ketentuan ini tercakup pada bagian kelima dari TRIPs yang mengatur tentang varietas unggul dibidang pertanian dan bernilai ekonomis tinggi tanpa mengabaikan pemanfaatan varietas tanaman baru tersebut bagi kesejahteraan seluruh masyarakat luas (Yuliati, 2003; 19). Maksud pemuliaan tanaman adalah mengembangkan varietas yang lebih baik dari yang sudah ada (Sugiono Moeljopawiro, Jurnal HKI, Volume 1).

Nilai komersial pemuliaan akan tercapai jika tersedia benih yang cukup untuk ditanam pada daerah yang cocok(Sugiono Moeljopawiro, Jurnal HKI, Volume 1). Penyebaran benih kepada para petani tersebut perlu diatur agar didapatkan manfaat dan dapat menyelesaikan masalah, untuk itulah dikeluarkan Undang Undang tentang PVT ini yang mengatur dan melindungi sistem PVT terkait dengan perbanyakan, distribusi, dan pemeliharaan varietas baru hasil pemuliaan tanaman. Pemegang hak PVT yaitu pemulia tanaman mempunyai hak eksklusif untuk memonopoli atas tanaman yang didaftarkan. Hak monopoli PVT terdiri atas memproduksi atau memperbanyak benih; menyiapkan untuk tujuan propagasi; mengiklankan; menawarkan; menjual atau memperdagangkan; mengekspor; mengimpor; mencadangkan untuk kegiatankegiatan sebelumnya. Selain hak eksklusif untuk memonopoli, dalam sistem PVT ini juga terkandung hak moral, yaitu hak untuk tetap dicantumkan namanya sebagai pihak pemulia tanaman meskipun hak milik ini telah diperalihkan kepada pihak lain, meskipun demikian, tidak semua pemulia tanaman memperoleh hak eksklusif atas varietas tanamannya. Tidak semua varietas tanaman yang dihasilkan oleh pemulia tanaman dapat dilindungi oleh sistem PVT, sehingga tidak semua pemulia tanaman dapat mendapatkan hak eksklusif tersebut.

Di Indonesia PVT merupakan salah satu jenis $\mathrm{HKI}$ yang dilindungi dengan Undang Undang Nomor 29 tahun 2000 tentang Perlindungan Varietas Tanaman. Berdasarkan pada Pasal 2 ayat (1) Undang Undang Nomor 29 tahun 2002, hanya varietas tanaman yang unik, baru, seragam, stabil, dan diberi nama saja yang dapat diberikan perlindungan. Persyaratan ini pada dasarnya diadopsi dari International convention for the protection of variety of plants (UpOv). Tujuan konvensi ini adalah untuk memberikan perlindungan kepada jenis tanaman baru dengan HKI (http://www.upov. int/index_en.html).

\section{Ketahanan Pangan sebagai Pemenuhan HAM}

Internasional confrence in Nutrition, (FAO/WHO, 1992) mendefenisikan ketahanan pangan sebagai akses setiap rumah tangga atau individu untuk memperoleh pangan pada setiap waktu untuk keperluan hidup sehat. Hasil Lokakarya Ketahanan Pangan Nasional (DEPTAN, 1996) mendefenisikan ketahanan pangan adalah kemampuan untuk memenuhi kebutuhan pangan anggota rumah tangga dalam jumlah, mutu dan ragam sesuai dengan budaya setempat dari waktu kewaktu agar dapat hidup Ketahanan pangan pada tataran nasional merupakan kemampuan suatu bangsa untuk menjamin seluruh penduduknya memperoleh pangan dalam jumlah yang cukup, mutu yang layak, aman, dan juga halal, yang didasarkan pada optimalisasi pemanfaatan dan berbasis pada keragaman sumber daya domestic. Selanjutnya, dalam Undang Undang No 7 tahun 1996 tentang pangan, pengertian ketahanan pangan adalah kondisi terpenuhinya pangan bagi rumah tangga yang tercermin dari ketersediaan yang cukup, baik dalam jumlah maupun mutunya, aman, merata dan terjangkau.

Dari pengertian tersebut, tersirat bahwa upaya mewujudkan ketahanan pangan nasional harus lebih dipahami sebagai pemenuhan kondisi kondisi : (1) terpenuhinya pangan dengan kondisi ketersediaan yang cukup, dengan pengertian ketersediaan pangan dalam arti luas, mencakup pangan yang berasal dari tanaman, ternak dan ikan dan memenuhi kebutuhan atas karbohidrat, vitamin dan mineral serta turunan, yang bermanfaat bagi pertumbuhan dan 
kesehatan manusia. (2) terpenuhinya pangan dengan kondisi aman, diartikan bebas dari pencemaran biologis, kimia, dan benda lain yang lain dapat mengganggu, merugikan, dan membahayakan kesehatan manusia, serta aman untuk kaidah agama. (3) terpenuhinya pangan dengan kondisi yang merata, diartikan bahwa distribusi pangan harus mendukung tersedianya pangan pada setiap saat dan merata di seluruh tanah air. (4) terpenuhinya pangan dengan kondisi terjangkau, diartikan bahwa pangan mudah diperoleh rumah tangga dengan harga yang terjangkau. Kemudian, Oxfam 2001 mendefinisikan Ketahanan Pangan sebagai kondisi ketika: "setiap orang dalam segala waktu memiliki akses dan kontrol atas jumlah pangan yang cukup dan kualitas yang baik demi hidup yang aktif dan sehat. Dua kandungan makna tercantum di sini yakni: ketersediaan dalam artian kualitas dan kuantitas dan akses (hak atas pangan melalui pembelian, pertukaran maupun klaim). Selanjutnya, FIvIMS (Food Insecurity and vulnerability Information and Mapping Systems, 2005 ) menyebutkan, ketahanan pangan adalah kondisi ketika semua orang pada segala waktu secara fisik, sosial dan ekonomi memiliki akses pada pangan yang cukup, aman dan bergizi untuk pemenuhan kebutuhan konsumsi (dietary needs) dan pilihan pangan (food preferences) demi kehidupan yang aktif dan sehat.. Salah satu indikator untuk mengukur ketahanan pangan adalah ketergantungan ketersediaan pangan nasional terhadap impor (Litbang Deptan, 2005).

Ketahanan pangan secara umum mencakup empat aspek, yaitu kecukupan (sufficiency), akses (access), keterjaminan (security), dan waktu (time) (Baliwaty , 2004). Adanya aspek tersebut maka ketahanan pangan dipandang menjadi suatu sistem, yang merupakan rangkaian dari tiga komponen utama yaitu ketersediaan dan stabilitas pangan (food availability dan stability), kemudahan memperoleh pangan (food accessibility) dan pemanfaatan pangan. Badan Pusat Statistik merilis data bahwa produksi beras nasional mencapai 37 juta ton, sementara itu kebutuhan diasumsikan 33,5 juta ton. Dengan demikian terjadi surplus. Namun surplus ini bersifat musiman, karena pada waktu tertentu justru terjadi kelangkaan beras sebagai salah satu sumber pangan. Jagung yang juga merupakan bahan pangan penting, produksi nasional mencapai 17,93 juta ton pipilang kering. Produksi ini turun 438,96 ribu ton apabila dibandingkan dengan produksi tahun yang lalu. Penyebabnya adalah penurunan luas lahan panen. Sementara itu, produksi ubi kayu hanya mencapai kisaran 21.756.991 ton dan untuk memenuhi kebutuhan pemerintah akan mengimpor ubi kayu dari negara lain. Ketidakstabilan produksi bahan pangan tersebut dan bahan pangan lainnya telah memaksa pemerintah untuk menyiapkan dana Rp. 3 triliyun untuk menjaga stabilitas ketahanan pangan tahun ini (BPS, 2 Oktober 2011). Presiden Susilo Bambang Yudhoyono menekankan ketahanan pangan harus jadi prioritas dan agenda nasional. Hal itu perlu dikonkritkan melalui program-program prorakyat yang harus terus dilaksanakan pemerintah. Empat agenda terkait pencapaian ketahanan pangan tersebut. Pertama, pemerintah terus mengembangkan program prorakyat, termasuk beras untuk rakyat miskin dan jaminan kesehatan untuk rakyat miskin. Kedua, produksi pangan harus terus ditingkatkan melalui perluasan lahan pertanian melalui bantuan teknologi, mengingat semakin terbatasnya ketersediaan lahan. Ketiga, komoditas pangan harus tersedia dengan harga terjangkau dan stabil. Keempat, perkembangan pangan pada tingkat global harus terus dipantau, sebab dibutuhkan kerjasama dengan negara-negara sahabat dan organisasi dunia untuk mencapai ketahanan pangan nasional (http://pse. litbang.deptan.go.id/ind/ pdffiles/Anjak 2005 IV_ 15 .pdf

Masalah ketahanan pangan harus menjadi prioritas nasional dengan penggeraknya adalah pemerintah daerah. Pemerintah daerahlah yang mengetahui kondisi sebenarnya tentang potensi dan keunggulan komoditi pangan yang dimiliki dengan dibantu oleh universitas setempat, Litbang Pertanian Daerah dan seluruh elemen masyarakat daerah. Dulu pemerintah kolonial Hindia Belanda pernah memperkenalkan Culture Stelsel. Culture stelsel adalah undangundang yang diberlakukan oleh pemerintah kolonial Belanda yang mewajibkan rakyat Indonesia menanam tanaman komoditi pertanian dan perkebunan, yang berlangsung sejak 1830-1970. Kenyataannya: Memang benar tanam paksa diadakan pada tahun sekitar itu, tetapi culture stelsel bukan berarti tanama paksa, melainkan aturan tanam baru yang dikeluarkan Belanda. 
Penerapan aturan tanam baru di Indonesia bukanlah sekedar aturan tetapi pemerintah Hindia Belanda menerapkannya setelah melalui beberapa kali penelitian oleh ahli-ahli pertanian pada saat itu untuk mengetahui komoditi pertanian seperti apa yang cocok dengan kondisi geografis suatu wilayah (Peta Komoditi Pertanian Indonesia). Dengan culture stelsel ini, Indonesia jadi mempunyai variasi tanaman yang semakin beragam, seperti jagung, coklat, dan teh. Selain menambah jenis tanaman yang baru, Indonesia jadi tahu bagaimana atau teknik menanam tanaman-tanaman baru itu.

Dengan mengembangkan keunggulan komoditi pertanian yang dimiliki oleh daerah, Indonesia tidak perlu ekspor apalagi impor. Jumlah penduduk 240 juta dapat menjadi pasar yang luar biasa bagi Indonesia. Jangan berpikir ekspor tetapi penuhi terlebih dahulu kebutuhan dalam negeri dengan memanfaatkan keunggulan komoditi masing $=$ masing daerah. Misalnya untuk memenuhi kebutuhan Jagung, Jawa dapat membelinya ke Sulawesi atau Nusa Tenggara. Untuk memenuhi kebutuhan bawang maka Kalimantan, Sulawesi, Maluku dan lain-lain dapat membeli ke Jawa. Jadi harus ada kekhususan komoditi pertanian suatu daerah sebagai komoditi pertanian unggulan.

Kebijakan yang komprehensif juga harus terlihat dalam penegakan hukum. Kalau sudah bicara ketahanan nasional berarti menjaga kehormatan bangsa. Kalau ada segelintir orang atau kelompok yang mencoba-coba bermain dan mengacaukan kepentingan pangan nasional demi keuntungan sendiri maka dapat disamakan dengan tindakan terorisme karena kepentingan pangan nasional identik dengan kepentingan kebutuhan primer rakyat Indonesia. Maka TNI/Polri secara otomatis turun tangan. Contoh yang terlihat jelas adalah masalah bawang merah. Seharusnya pemerintah pusat segera menurunkan para intel untuk mengawasi masuknya bawang impor yang masuk ke Indonesia. Terjunkan para intel untuk mengawasi dan memata-matai mereka yang ingin merusak aturan main yang sudah dibuat karena berkaitan dengan masalah nasional.

Ketahanan pangan nasional setelah terjadi krisis ekonomi global mempengaruhi juga krisis pangan ini disebabkan semakin sulit untuk mencari penghasilan untuk mendapatkan pangan. Selain itu, petani juga menjadi sulit mencari bibit-bibit pangan. Di sini sudah mulai dirasakan ketika pangan yang berupa beras makin sulit di dapat di negeri sendiri sampai beras impor pun masuk ke Indonesia. Sungguh ironis negara yang disebut sebagai lumbung padi harus mendapatkan beras impor yang lebih murah dari pada beras lokal. Dari sinilah permintaan masyarakat nasional akan beras impor terus meningkat yang membuat padi yang ditanam oleh petani lokal pun mulai tergusur dengan kedatangan beras impor. Akhirnya petani terpaksa menjual tanah atau ladang persawahan miliknya tanpa disadari berimbas semakin berkurangnya lahan pertanian yang ada di Indonesia. Ini pun dihubungkan dengan kemajuan industri yang begitu tinggi di Indonesia yang tanpa disadari oleh pemerintah, memberikan izin beroperasi perusahaan asing di Indonesia yang mengunakan lahan hijau. Ini sungguh ironis ketika negara maju sudah mengantisipasi krisis pangan global agar dapat bertahan dengan pasokan yang ada di negeri mereka. Dalam hal ini nampak tidak ada gairah membantu para petani dari segi pendanaan secara sistem ikhlas yang ditujukan agar tidak ada beban kepada petani dengan berpikir tentang cara mengembalikan uang tersebu. Dalam Undang-Undang Republik Indonesia Nomor 7 Tahun 1996 disebutkan, bahwa ketahanan pangan diwujudkan bersama oleh masyarakat dan pemerintah dan dikembangkan mulai tingkat rumah tangga. Apabila setiap rumah tangga Indonesia sudah mencapai tahapan ketahanan pangan, maka secara otomatis ketahanan pangan masyarakat, daerah dan nasional akan tercapai, jadi disini dapat disimpulkan bahwa dari kepedulian untuk akan pangan dari rumah tangga akan berimbas pada seluruh nasional, cara ini memang baik tapi bagaimana pun masih ada kendala dalam pelaksakannya.

Ketahanan pangan merupakan salah satu hak asasi manusia warganegara, negara bertanggung jawab atas tercapainya ketahanan pangan ini. Dalam Pasal 11 International covenant on Economic, Social and cultural rights (ICESCr) dinyatakan:

a. The States parties to the present Covenant recognize the right of everyone to an adequate standard of living for himself and his family, including adequate food, clothing and housing, and to the continuous improvement of living 
conditions. The States parties will take appropriate steps to ensure the realization of this right, recognizing to this effect the essential importance of international co-operation based on free consent.

b. The States Parties to the present Covenant, recognizing the fundamental right of everyone to be free from hunger, shall take, individually and through international co-operation, the measures, including specific programmes, which are needed:

1) To improve methods of production, conservation and distribution of food by making full use of technical and scientific knowledge, by disseminating knowledge of the principles of nutrition and by developing or reforming agrarian systems in such a way as to achieve the most efficient development and utilization of natural resources;

2) Taking into account the problems of both food-importing and foodexporting countries, to ensure an equitable distribution of world food supplies in relation to need.

Dengan demikian setiap negara harus mengakui hak setiap orang atas standar hidup yang layak, termasuk pangan. Negara harus mengambil langkah-langkah memadai untuk menjamin perwujudan hak ini dengan mengakui arti penting kerjasama internasional yang berdasarkan kesepakatan sukarela. Negara mengakui hak mendasar dari setiap orang untuk bebas dari kelaparan, baik secara individual maupun melalui kerjasama internasional. Oleh karena itu, negara harus mengambil langkah-langkah termasuk program-program khusus yang diperlukan untuk meningkatkan cara-cara produksi, konservasi dan distribusi pangan. Negara juga harus memastikan distribusi pasokan pangan dunia yang adil yang sesuai kebutuhan, dengan memperhitungkan masalah Negaranegara pengimpor dan pengekspor pangan.

Indonesia sudah meratifikasi IcEScr dengan Undang Undang Nomor UU No 11 Tahun 2005. Oleh karena itu, Indonesia terikat untuk melaksanakan ketentuan IcEScr

3. Identifikasi Hukum yang Mengatur PVT, Pangan, dan Ketahanan Pangan Nasional

Undang Undang Nomor 29 tahun 2000 tentang Perlindungan Varietas Tanaman pada dasarnya juga ditujukan untuk ketahanan pangan nasional. Adanya penghargaan kepada pemulia tanaman dan terjaminnya karya intelektualitas mereka akan mendorong pemulia tanaman untuk menciptakan sebuah varietas baru yang lebih membawa manfaat kepada masyarakat. Data hasil penelitian yang pernah penulis lakukan menunjukkan bahwa varietas yang diajukan pendaftarannya merupakan varietas pangan dengan beberapa keunikan baru dan lebih menguntungkan bagi terciptanya ketahanan pangan.

Pendaftaran PVT pada kementerian pertanian mensyaratkan adanya beberapa uji agar varietas tersebut aman untuk didistribusikan dan diproduksi. Uji yang dimaksud juga merupakan salah satu proses untuk memenuhi ketentuan tentang pangan. Berdasarkan hal tersebut, terdapat keterkaitan antara ketentuan yang mengatur perlindungan varietas tanaman, pangan, dan ketahanan pangan, baik secara vertikal maupun secara horizontal. Melalui kajian sinkronisasi hukum semacam ini dapat ditemukan urgensi peraturan-peraturan yang terkait perlindungan varietas tanaman di berbagai hukum positif yang ada di Indonesia. Secara horizontal ada beberapa peraturan yang saling terkait yang mengatur tentang perlindungan varietas tanaman, pangan, dan ketahanan pangan.

Beberapa peraturan yang saling terkait tersebut antara lain sebagai berikut.

a. Undang Undang Nomor 29 tahun 2000 tentang Perlindungan Varietas Tanaman.

Undang Undang ini merupakan landasan hukum perlindungan varietas tanaman hasil pemuliaan tanaman. dengan adanya Undang Undang ini diharapkan muncul kegairahan bagi para petani dan pemulia tanaman untuk menciptakan varietas baru yang dapat mendukung terciptanya ketahanan pangan nasional

b. Undang Undang Nomor 4 Tahun 2006 tentang Pengesahan International Treaty on plant genetic resources for Food and Agriculture (Perjanjian Mengenai Sumber Daya Genetik Tanaman untuk Pangan dan Pertanian).

Perjanjian Mengenai Sumber Daya Genetik Tanaman untuk Pangan dan Pertanian bertujuan untuk menciptakan ketahanan pangan internasional dan pembangunan pertanian secara berkelanjutan. Tujuan kedua adalah untuk 
melestarikan dan memanfaatkan sumber daya genetik dengan memberikan penghargaan kepada petani karena telah menyediakan sumber daya genetika yang akhirnya dapat dimanfaatkan oleh masyarakat luas. Salah satu bentuk penghargaan ini adalah melalui sistem $\mathrm{HKI}$, salah satunya adalah melalui PVT yang telah diatur melalui Undang Undang Nomor 29 tahun 2000

c. Undang Undang Nomor 5 tahun 1994 tentang Pengesahan United Nation convention on Biological Diversity (Konvensi Perserikatan Bangsa-Bangsa Mengenai Keanekaragaman Hayati)

Konvensi Keanekaragaman Hayati $(\mathrm{KKH})$ memuat kesepakatan internasional untuk konservasi dan pemanfaatan berkelanjutan sumber daya hayati serta menunjang adanya pembagian keuntungan yang adil dalam pemanfaatan komponen-komponen sumber daya genetik tersebut. Dalam konvensi ini telah digariskan pula kesepakatan mengenai perlunya pengaturan hak-hak atas plasma nutfah (sumber daya genetik/ SDG), hak-hak petani, keamanan hayati, hak-hak kepemilikan intelektual dan lain sebagainya (Kusuma Dwiyanto dan Bambang Setiadi).

d. Undang Undang Nomor 12 Tahun 1992 tentang Sistem Budidaya Tanaman

Secara umum UU PVT dan UU Sistem budidaya tanaman mendorong pengembangan benih berkualitas unggul, akan tetapi kedua peraturan ini juga mempunyai dampak negatif, API mengklaim bahwa kedua UU ini akan mengancam varietas lokal (Nurul Barizah,http://twnindonesia. info/ index2.php?option=com_content\&do_ pdf=1\&id=55)

Undang Undang Nomor 29 tahun 2000 merupakan pengejawantahan dari Perjanjian TRIPs Agreement yang mengamanahkan diaturnya perlindungan tentang varietas tanaman secara sui generis bagi tiap-tiap negara, sehingga secara vertikal Undang Undang ini diturunkan dari TRIPs Agreement. Undang Undang Nomor 29 tahun 2000 ini memerlukan Peraturan Pelaksana agar dapat dikonkritkan dalam masyarakat. Ada tujuh peraturan pelaksana yang mengatur tentang perlindungan varietas tanaman, yaitu sebagai berikut. a. Peraturan Pemerintah Republik Indonesia No. 13 tahun 2004 tentang Penamaan, Pendaftaran dan Penggunaan Varietas Turunan Esensial;

Peraturan Pemerintah ini menjabarkan lebih jauh tentang persyaratan yang disebutkan dalam UU No 29 tahun 2000 seperti persyaratan keunikan, kebaruan, keseragaman, kestabilan, dan pemberian nama atas varietas yang dimohonkan perlindungan perlindungan varietas tanaman.

b. Peraturan Pemerintah Republik Indonesia No. 14 tahun 2004 tentang Syarat dan Tata Cara Pengalihan Perlindungan Varietas Tanaman dan Penggunaan Varietas yang Dilindungi oleh Pemerintah;

Peraturan Pemerintah ini mengatur secara lebih lanjut ketentuan Pasal 40 - 55 UU No 29 tahun 2000 tentang tata cara pengalihan varietas tanaman yang dilindungi oleh pemerintah.

c. Keputusan Menteri Pertanian No. 442/ Kpts/HK.310/7/2004 tentang Syarat dan Tata Cara Permohonan dan Pemberian Hak Perlindungan Varietas Tanaman;

Keputusan Menteri Pertanian ini mengatur secara lebih lanjut ketentuan Pasal 11-20 UU No 29 tahun 2000.

d. Keputusan Menteri Pertanian No. 443/Kpts/KU.330/7/2004 tentang Biaya Pengelolaan Hak Perlindungan Varietas Tanaman;

Keputusan Menteri Pertanian ini merupakan ketentuan yang mengatur secara lebih lanjut ketentuan Pasal 63 ayat (1) UU No 29 tahun 2000 tentang biaya pengelolaan PVT.

e. Keputusan Menteri Pertanian No. 444/Kpts/OT.160/7/2004 tentang Pembentukan Komisi Perlindungan Varietas Tanaman;

Keputusan Menteri Pertanian ini merupakan ketentuan yang mengatur secara lebih lanjut ketentuan Pasal 65 ayat (2) UU No 29 tahun 2000 tentang pembentukan Komisi Perlindungan Varietas Tanaman.

f. Keputusan Menteri Pertanian No. 445/ Kpts/OT.140/7/2004 tentang Susunan Organisasi dan Tata Kerja Komisi Banding Perlindungan Varietas Tanaman;

Keputusan ini merupakan tindak lanjut dari ketentuan Pasal 36 ayat (4) UU No 29 tahun 2000 
g. Keputusan Menteri Pertanian No. 446/ Kpts/HK.310/7/2004 tentang Syarat dan Tata Cara Pendaftaran Konsultan Perlindungan Varietas Tanaman;

Keputusan ini merupakan tindak lanjut dari ketentuan Pasal 1 huruf 6, jo Pasal 12 ayat (2) dan (3), dan Pasal 13 ayat (1), (2) UU No 29 tahun 2000

Pasal yang menjadi pokok pengaturan Perlindungan Varietas Tanaman dan kaitannya dengan ketahanan pangan dalam perspektif Undang Undang Nomor 29 tahun 2000 tentang Perlindungan Varietas Tanaman dan UUD 1945 ialah sebagai berikut.

Berdasarkan Pasal 33 UUD 1945 dapat dilihat bahwa ada jaminan kekayaan alam yang terkandung di dalam bumi Indonesia yang dalam hal ini adalah varietas baru tanaman dikuasai oleh negara dan dipergunakan untuk sebesar-besar kemakmuran rakyat. Dalam konteks pembangunan, terdapat interaksi antara kepastian hukum dan ekonomi yang saling membutuhkan satu dengan yang lain. Amanat dasar antara hukum dan ekonomi di Indonesia dapat dilihat prinsipnya dalam hukum dasar negara, yaitu Pasal 33 Undang Undang Dasar 1945. Inti prinsip dasar dimaksud tersirat tegas antara lain dianutnya sistem demokrasi (khusus segi ekonomi) dengan prinsip kekeluargaan, kebersamaan, efisiensi berkeadilan, berkelanjutan, berwawasan lingkungan, kemandirian, serta dengan menjaga keseimbangan kemajuan dan kesatuan ekonomi nasional dalam hal maksud pengusahaan perekonomian yang dijalankan hingga negara mutlak/wajib terlibat jika cabang produksi ekonominya penting bagi negara yang menguasai hajat hidup orang banyak hingga tujuan akhirnya mutlak pula dipergunakan untuk sebesar-besar kemakmuran rakyat. Hal tersebut dapat dikatakan bahwa itu sebagai arah kebijakan nasional. Dianutnya sistem demokrasi ekonomi dalam Pasal 33 Undang Undang Dasar 1945 tersebut hingga melahirkan hak ekonomi individu. Hak ekonomi individu itu kemudian dapat direpresentasikan sebagai persaingan antar individu (masyarakat) guna menghasilkan barang dan jasa.

Definisi/pengertian Perlindungan Varietas Tanaman (selanjutnya disingkat PVT) dapat dilihat dalam Pasal 1 angka 1 Undang Undang Nomor 29 Tahun 2000 Tentang Perlindungan Varietas Tanaman , yaitu, "perlindungan varietas Tanaman adalah perlindungan khusus yang diberikan negara, yang dalam hal ini diwakili oleh pemerintah dan pelaksanaannya dilakukan oleh Kantor perlindungan varietas Tanaman, terhadap varietas tanaman yang dihasilkan oleh pemulia tanaman melalui kegiatan pemuliaan tanaman".

Jika dilihat pada pengertian tersebut tergambar tegas bahwa negara berhak memberikan perlindungan varietas tanaman yang dihasilkan oleh pemulia tanaman melalui kegiatan pemuliaan tanaman. Pengertian berhak di sini jika kemudian menggunakan intrumen Undang Undang dimaksud untuk lebih jauh mencari definisinya, maka diketahui bahwa hak yang diberikan negara adalah hak khusus yang diberikan kepada pemulia untuk menggunakan sendiri hasil pemuliaannya atau bahkan dapat pula memberikan persetujuannya kepada pihak lain untuk menggunakannya.

Selanjutnya, pada bagian pertimbangan Undang Undang perlindungan varietas tanaman telah dipertegas bahwa "Negara republik Indonesia adalah negara agraris, maka pertanian yang maju, efisien, dan tangguh mempunyai peranan yang penting dalam rangka pencapaian tujuan pembangunan nasional", sehingga untuk membangun pertanian yang maju, efisien, dan tangguh perlu didukung dan ditunjang antara lain dengan tersedianya varietas unggul". Untuk itulah guna lebih meningkatkan minat dan peran serta perorangan maupun badan hukum untuk melakukan kegiatan pemuliaan tanaman dalam rangka menghasilkan varietas unggul baru, kepada pemulia tanaman atau pemegang hak Perlindungan Varietas Tanaman perlu diberikan hak tertentu serta perlindungan hukum atas hak tersebut secara memadai.

Pada dasarnya regulasinya tersebut tidak lain tujuannya hanya untuk melindungi, membatasi, dan menetapkan peraturan di bidang Varietas Tanaman. Beberapa aturan tersebut juga tugasnya yaitu melindungi hak para pemulia tanaman atas varietas tanaman yang dihasilkannya melalui kegiatan pemuliaan tanaman, yang mana karya yang dihasilkannya dengan hak yang mengandung nilai ekonomi. Di lain hal regulasi tersebut dapat pula dijadikan sandaran akan kepastian hukum bagi para masyarakat (http://www. facebook.com/note.php?note_id=18973930 1050489). Dengan demikian ada kesinkronan antara UU PVT dan UUD 1945 (Pasal 33). 
Dalam Pasal 10 ayat (1) Peraturan Pemerintah Republik Indonesia No. 13 tahun 2004 diatur bahwa dalam hal perjanjian sebagaimana dimaksud dalam Pasal 9 mengatur tentang imbalan bagi pemilik varietas asal, maka imbalan tersebut digunakan untuk peningkatan kesejahteraan masyarakat pemilik varietas Lokal; dan konservasi varietas lokal yang bersangkutan dan upaya-upaya pelestarian plasma nutfah di daerah tempat varietas lokal tersebut. Selanjutnya, Pasal 7 ayat (1) UU Nomor 29 Tahun 2000 dinyatakan varietas lokal milik masyarakat dikuasai oleh negara. Ayat (2) Penguasaan oleh negara sebagaimana dimaksud pada ayat (1) dilaksanakan oleh Pemerintah.

Dalam Pasal 9 huruf i-vi Undang Undang Nomor 12 Tahun 1992 dinyatakan bahwa (ii) Penemuan varietas unggul dilakukan melalui kegiatan pemuliaan tanaman, (iii) Pencarian dan pengumpulan plasma nutfah dalam rangka pemuliaan tanaman dilakukan oleh Pemerintah, (iv) kegiatan pencarian dan pengumpulan plasma nutfah sebagaimana dimaksud dalam ayat (2), dapat dilakukan oleh perorangan atau badan hukum berdasarkan izin, (v) Pemerintah melakukan pelestarian plasma nutfah bersama masyarakat, (vi) ketentuan mengenai tata cara pencarian, pengumpulan, dan pelestarian plasma nutfah sebagaimana dimaksud dalam ayat (2), ayat (3), dan ayat (4), diatur lebih lanjut dengan Peraturan Pemerintah.

Selanjutnya dalam Pasal 7 ayat (14) dinyatakan bahwa (1) Varietas lokal milik masyarakat dikuasai oleh Negara, (2) Penguasaan oleh Negara sebagaimana dimaksud pada ayat (1) dilaksanakan oleh Pemerintah, (3) Pemerintah berkewajiban memberikan penamaan terhadap varietas local sebagaimana dimaksud pada ayat (1)., (4) Ketentuan penamaan, pendaftaran, dan penggunaan varietas local sebagaimana dimaksud pada ayat (1), ayat (2), dan ayat (3), serta instansi yang diberi tugas untuk melaksanakannya, diatur lebih lanjut oleh Pemerintah.

Faktanya, perlindungan pemerintah terhadap petani pemulia benih sangat kurang, bahkan di kediri ditemukan fakta ada 14 petani pemulia benih jagung yang merupakan anggota Aliansi Petani Indonesia dikriminalisasi oleh UU Sistem Budidaya Tanaman (http://padiberas.com /?p=189), sehingga terlihat bahwa Undang Undang
Nomor 29 tahun 2000 dan Undang Undang Nomor 12 Tahun 1992 masih tumpang tindih dalam pelaksanaannya.

Akibat hukum dapat timbul terhadap orang perseorangan maupun korporasi yang dianggap telah melanggar aturan hukum varietas tanaman, dapat terkena dampak hukum pidana, misalnya jika ada orang perseorangan atau korporasi yang dengan sengaja tanpa persetujuan pemegang hak varietas tanaman misalnya telah memproduksi atau memperbanyak benih, maka bukan tidak mungkin dapat dikenakan penjara selama 7 (tujuh) tahun lamanya. Atau bahkan dapat saja dimungkinkan yang terjadi misalnya pelakunya adalah masyarakat industri negara lain, sebagaimana misalnya telah memproduksi benih hingga terlanjur terkomersialisasikan secara global. Terhadap kasus seperti itu maka penyelesaianya dapat terselesaikan melalui forum internasional (WTO), dan di Indonesia sendiri penegakan hukumnya dapat dilakukan oleh Badan Peradilan dan Badan Administrasi.

UU PVT tidak secara eksplisit menyebut tentang partisipasi masyarakat. Padahal dalam kaitannya dengan pemuliaan varietas, masyarakat lokal telah melakukannya selama ratusan tahun. Metode pengelolaan varietas tanaman oleh masyarakat lokal tidak dianggap sebagai partisipasi oleh UU ini. UU ini lebih banyak menyebut tentang Hak Perlindungan Varietas Tanaman yang merupakan hak khusus yang diberikan negara kepada pemulia dan/atau pemegang hak Perlindungan Varietas Tanaman. Dengan begitu lebih terkait dengan ijin daripada peran serta masyarakat (http://huma.or.id/ wp-content/uploads/2006/08/Desentralisasikoordinasi-dan-partisipasi-masyarakat_ Steny. pdf)

4. Pemutakhiran Peraturan Perundangundangan yang Mengatur PVT dan Pangan Menuju Ketahanan Pangan Nasional

Setidaknya ada enam kajian perubahan Undang Undang terkait dengan perlindungan varietas tanaman, pangan dan ketahanan pangan nasional yang didasarkan pada daftar rancangan Undang Undang Program Legislasi Nasional tahun 2010-2014, yaitu:

a. RUU tentang Perubahan atas Undang Undang Nomor 29 Tahun 2000 tentang Perlindungan Varietas Tanaman 
b. RUU tentang Perubahan atas Undang Undang Nomor 7 Tahun 1996 tentang Pangan

c. RUU tentang Pelestarian dan Pemanfaatan Sumber Daya Genetik

d. RUU tentang Keanekaragaman Hayati

e. RUU tentang Hortikultura

f. RUU tentang Perlindungan dan Pemberdayaan Petani

Dari enam daftar rancangan Undang Undang Program Legislasi Nasional tahun 2010-2014 di atas baru dua Rancangan Undang Undang yang telah disahkan menjadi Undang Undang, yaitu : Kesatu, Undang Undang Nomor 13 tahun 2010 tentang Hortikultura yang telah disahkan pada tahun 2010 dan. Dasar dikeluarkannya Undang Undang ini adalah kedudukan tanaman hortikultura sebagai kekayaan hayati merupakan salah satu kekayaan sumber daya alam Indonesia yang sangat penting sebagai sumber pangan bergizi, bahan obat nabati, dan estetika, yang bermanfaat dan berperan besar dalam meningkatkan kualitas hidup masyarakat, yang perlu dikelola dan dikembangkan secara efisien dan berkelanjutan. Alasan lainnya adalah bahwa peraturan perundang undangan yang ada belum dapat memberikan kepastian hukum dalam pengembangan hortikultura sesuai dengan perkembangan dan tuntutan dalam masyarakat. Kedua, Undang-Undang No 18 tahun 2012 tentang Pangan. Salah satu latar belakang dikeluarkannya Undang-undang ini adalah karena Undang-Undang Nomor 7 Tahun 1996 tentang Pangan sudah tidak sesuai lagi dengan dinamika perkembangan kondisi eksternal dan internal, demokratisasi, desentralisasi, globalisasi, penegakan hukum, dan beberapa peraturan perundangundangan lain yang dihasilkan kemudian sehingga perlu diganti. Pemerintah dan Dewan Perwakilan Rakyat (DPR) sepakat bahwa UU Pangan yang baru ini akan dapat menjadi pedoman dan mengakomodir permasalahanpermasalahan di bidang pangan yang ada di negeri ini. UU Pangan yang baru ini sampai saat tulisan ini ditulis belum mampu menjawab masalah yang ada dan tidak mampu mengubah kehidupan petani dan nelayan sebagai produsen pangan. Dalam UU Pangan yang baru disahkan, SPI melihat Pemerintah terkesan memaksakan konsep kedaulatan pangan dan ketahanan pangan untuk disatukan dalam UU. Pada tahun yang sama dikeluarkan pula Inpres nomor 3 tahun 2012 tentang Kebijakan Pengadaan Gabah/Beras dan Penyaluran Beras Oleh Pmerintah Dalam rangka stabilisasi ekonomi nasional, melindungi tingkat pendapatan petani, stabilisasi harga beras, pengamanan Cadangan Beras Pemerintah, dan penyaluran beras untuk keperluan yang ditetapkan oleh Pemerintah serta sebagai kelanjutan Kebijakan Perberasan. Selanjutnya, pada tahun 2013 dikeluarkan Peraturan Presiden Republik Indonesia Nomor 32 Tahun 2013 Tentang Penugasan Kepada Perusahaan Umum Bulog Untuk Pengamanan Harga dan Penyaluran Kedelai dengan beberapa keunikan baru dan lebih menguntungkan bagi terciptanya ketahanan pangan.

\section{d. Simpulan}

Perlindungan varietas tanaman merupakan salah satu bentuk perlindungan hak ekonomi para pemulia tanaman. Meskipun tiap-tiap daerah mempunyai potensi atas varietas unggul yang dapat dimintakan permohonan PVT tetapi pengetahuan masyarakat dan instansi terkait tentang perlindungan varietas tanaman masih kurang . Perundang-undangan di bidang PVT dan pangan belum mampu mendorong pemulia varietas tanaman menghasilkan bibit unggul tanaman pangan karena belum dapat melindungi hak ekonomi mereka. Dari enam daftar rancangan Undang Undang Program Legislasi Nasional tahun 2010-2014 di atas baru dua Rancangan Undang Undang yang telah disahkan menjadi Undang Undang, yaitu Undang Undang Nomor 13 tahun 2010 tentang Hortikultura yang telah disahkan pada tahun 2010 dan Undang-Undang No 18 tahun 2012 tentang Pangan. Pada tahun yang sama juga dikeluarkan pula Inpres nomor 3 tahun 2012, pada tahun 2013 dikeluarkan Peraturan Presiden Republik Indonesia Nomor 32 Tahun 2013. 


\section{daftar Pustaka}

Akira Okawa. 1997. Major Provisions under WTO-TRIPs Agreement. Paper. Industrial Property Rights Training Course for Management. Tokyo. Japan : JIII \& AOTS. Akira Okawa. 1997. Major provisions under WTO-TRIPs Agreement. Paper. Industrial property rights Training course for Management. Tokyo : JIII \& AOTS.

Andy Noorsaman Sommeng .2002. "Relevansi Relevansi Kekayaan Intelektual terhadap Usaha Kecil danMenengah ". Naskah power point. Disampaikan dalam Sosialisasi HKI bagi Aparatur Pemerintah Daerah Propinsi, Kabupaten/Kota yang Membidangi Koperasi Dan Usaha Kecil dan Menengah Makassar, 21 Oktober 2002 . http://www.dgip.go.id/ article/ articleview/60/1/15/ [20 November 2004].

,Anonim. 1994. Kompilasi Undang-Undang republik Indonesia di Bidang Hak Kekayaan Intelektual. Tangerang : Ditjen HKI Depkeh \&HAM RI dan JICA

. 1997. Agreement on Trade Related Aspect of Intelectual Property Rights (TRIPs Agreement) (1994). GENEVA : WIPO.

-2004. International covenant on Economic, Social and cultural rights .(Kovenan Internasional tentang Hak-hak Ekonomi, Sosial dan Budaya)

.2005. UU No 11 Tahun 2005 tentang Pengesahan International covenant on Economic, Social and cultural rights (Kovenan Internasional tentang Hak-hak Ekonomi, Sosial dan Budaya) .

AusAID. 2001. Intellectual property Law (patent and Design). Jakarta: Asian Law Group.

A. Zen Umar Purba. 2002 "Traditional Knowledge Subject Matter For Which Intellectual protection is Sought". Paper. WIPO Asia-Pacific Regional Symposium on Intellectual Property Rights, Traditional Knowledge and Related Issues, October 17 to 19. Yogyakarta: WIPO \& DGIPR.

Ary Aviantoro. 2012. "Studi Pembuatan Kudapan Tiwul Instan dari Tepung Ubi Kayu (Mannihot Utillisima) Varietas Kaspro dengan Penambahan Berbagai Jenis Tepung Kacang-kacangan" Tesis. Malang: Universitas Muhammadiyah.

Badan Pusat Statistik Kota Semarang. 2012

Bambang Kesowo. 1997. “Implementasi Persetujuan TRIP's dalam Hukum Hak Atas Kekayaan Intelektual Nasional". Makalah. Disampaikan dalam Seminar Nasional Perlindungan Konsumen dalam Era Pasar Bebas tanggal 15 Maret 1997 di Fakultas Hukum UNS. Surakarta: Fakultas Hukum UNS.

Budi Agus Riswandi dan M. Syamsuddin. 2005. Hak Kekayaan Intelektual dan Budaya Hukum,. Jakarta: PT Raja Grafindo Persada

http://krjogja.com. Produksi Pangan Non Beras di Klaten Rendah [19 Juli 2012]

http://www.wipo.int/about-ip/en/. 2009. “What is Intellectual Property?”. [21 Januari 2013].

Insan Budi Maulana. 2007. "Paten Dalam Bingkai AL-Qur’an : Pendekatan Sejarah dan Hukum”. pidato pengukuan guru Besar. Jakarta: Fakultas Hukum Krisnadipayana.

JICA Team.2003. Capacity Building Program on the Implementation of the WTO Agreements in Indonesia (TripS cOMpONENT), Training Material on Enforcement of Intellectual property rights. Jakarta: DGIPR.

Kusuma Diwyanto dan Bambang Setiadi. tt. "Peran Komisi Nasional Plasma Nutfah dalam Pengelolaan Pemanfaatan dan Pelestarian Sumberdaya Genetik Pertanian". Artikel Komisi Nasional Sumber Daya genetik.

Muhamad Djumhana dan R. Djubaedillah.1996. Hak Milik Intelektual (Sejarah Teori dan prakteknya di Indonesia). Bandung: Citra Aditya Bakti.

..2006. perkembangan dan Teori perlindungan Hak Kekayaan Intelektual. Bandung: Alumni

Neni Sri Imaniyati.2010. "Perlindungan HKI sebagai Pemenuhan Hak atas IPTEK, Budaya, dan Seni”. Jurnal Media Hukum, volume 17 No 1, Juni 2010. 
New York Times. 1999, 9 April.

Ok Saidin. 2004. Aspek Hukum Hak Kekayaan Intelektual (Intelectual Property Rights) ${ }_{2}$ Jakarta: PT Raja Grafindo Persada.

Prasetyo Hadi Purwandoko. 1999. "Implikasi Ketentuan Agreement on TRIPs bagi Indonesia".. Yustisia No 47 Tahun XIII September - Nopember. Surakarta: Fak. Hukum UNS.

2010. "Pokok-pokok Hak Kekayaan Intelelktual". Makalah. Disampaikan dalam Workshop Technical Assistance Hak Kekayaan Intelektual, Selasa - Rabu, 21-22 September 2010, di AULA Fakultas pertanian Universitas palangkaraya.

1999. "Merek Suatu Telaah Singkat”. Makalah. Disampaikan dalam Pelatihan HaKI bagi Mahasiswa dan Dosen UNS yang memiliki Karya Inovatif tanggal 1-2 Juli 1999. .1999.. "Merek dan Perlindungan Hukumnya". Harian Umum pos Kita Solo 5 Oktober 1999.

Priharniwati. 2004. "Peranan Direktorat Jenderal Hak Kekayaan Intelektual (Ditjen HKI) dalam Pembangunan Ekonoml". Makalah. Disampaikan pada Seminar Nasional Hubungan antara Penegakan Hukum HKI dan Pembangunan Ekonomi, tanggal 28 Sptember, di Hotel Sheratom Bandung.

Richard Burton Simatupang. 1996. Aspek Hukum dalam Bisnis. Jakarta: Rineka Cipta.

Sugiono Moeljopawiro, "Penelitian dan Pengembangan Varietas Tanaman Berbasis Hak Kekayaan Intelektual”. Jurnal HKI, volume 1, Januari 2011. Surakarrta: LPPM, UNS.

Tim Lindsey. dkk. 2005. Hak Kekayaan Intelektual Suatu pengantar. Bandung: PT Alumni.

Titik Sundari. tt. "Petunjuk Teknis PengenalanVarietas Unggul dan Teknik Budi Daya Ubi Kayu". Malang: Balai Penelitian Kacang-kacangan dan Umbi-umbian,

Weni Nurcahyani.2012. "Analisis Ketahanan Pangan Kota Semarang Tahun 2006-2010". Skripsi. Semarang: Universitas Negeri Semarang.

Widiyanti, dkk, "Keragaman Padi (Oryza Sativa) Varietas Rojolele Berdasarkan Morfologi Biji Dan Pola Pita Isozimnya". artikel.

Yuliati. 2003. Jurnal Hukum Legality, Agustus 2003. Malang: Universitas Muhammadiyah .

Zaid Hamzah. 2007. Intellectual property Law \& Strategy. Singapore: Thomson/ Sweet\&Maxwell Asia. 